\title{
Immunolcocalization of actin in intact and DNA- and histone-depleted nuclei and chromosomes of allium cepa
}

\author{
WAN Li Hong, Miao Xin G ${ }^{1}$ \\ Institute of Genetics and Cytology, Northeast Normal Uni- \\ versity, Changchun 130024, China
}

\section{ABSTRACT}

The presence of actin in eukaryotic nuclei and chromosomes, and especially in higher plant nuclei and chromosomes, has not been well established. We detected actin in meristematic cells of Allium cepa with indirect immunofluorescence technique and observed bright fluorescence in the intact nuclei and chromosomes, indicating that actin is present in the nuclei and chromosomes of the higher plant. We labeled sections of the meristematic cells of A. cepa with immunogold technique, gold particles were found over the whole nuclei and a number of gold particles were concentrated in condensed chromatin and nucleoli, confirming the results of the immunofluoresence observations. We treated the nuclei and chromosomes of A. cepa with DNase I and $2 \mathrm{M} \mathrm{NaCl}$ and obtained DNA- and histone-depleted nuclei and chromosomes. Indirect immunofluorescence tests showed that the DNA- and histonedepleted nuclei and chromosomes reacted positively with the anti-actin antibodies. These results demonstrate that actin exists not only in intact nuclei and chromosomes, but also in DNA- and histone-depleted nuclei and chrmosomes of the plant. In addition, our immuno-fluorescence tests indicate that tropomyosin is present in the nuclei and chromosomes of A. cepa.

Key words: Actin, Allium cepa, chromosomes, nuclei.

1. Author for correspondence: Miao XING, Institute of Genetics and Cytology, Northeast Normal University, Changchun 130024, Jilin Province, China. Fax: 86-431-5684009, Tel: 86-431-5684088, e-mail: xingm@ivy.nenu.edu.cn. 
Actin in higher plant nuclei and chromosomes

\section{INTRODUCTION}

Actin is a contractile protein which was first isolated from vertebrate muscular cells. A large volume of evidence have indicated that actin occurs as an important cytoskeletal protein in both muscular and non-muscular cells of eukaryotes[1]. Since the 70's, biochemical analysis of animal and lower plant cells have showed that actin is one of the non-histone proteins of the nuclei and chromatin[2-12], and many functions have been attributed to nuclear actin including the condensation of chromosomes[13], nuclear transportation[14], and transcription and processing of RNA[15]. Recently, immunofluorescence microscopy, immunoelectron microscopy, confocal imaging and Western blot analysis have been combined to localize actin in the nuclei and chromatin of animal cells[16-19]. However, the study of actin in the nuclei and chromosomes of higher plants has been limited.

Some previous biochemical studies suggested that actin is present in the nuclear matrix of mammalian cells[14, 20]. In contrast, there was a report that actin-like polypeptide revealed by SDS-PAGE in the chromosome scaffold of bovine liver cells is the contamination of the cytoplasmic components[21]. Since many studies used isolated nuclear matrices and chromosome scaffolds, the question of adventitious association of actin with the nuclear matrices and chromosome scaffolds would be difficult to answer. In order to confirm the presence of actin in these infra-nuclear and infra-chromosome structures, it is necessary to localize actin in situ.

In this paper, immunofluorescence and immunogold techniques were used to demonstrate actin in intact nuclei and chromosomes of meristematic cells of A11ium cepa. We treated the nuclei and chromosomes with DNase I and $2 \mathrm{M} \mathrm{NaCl}$, obtained the DNA- and histone-depleted nuclei and chromosomes, and immunolocalized actin in these treated nuclei and chromosomes in situ. In addition, tropomyosin localized was also in the nuclei and chromosomes with immunofluorescence technique.

\section{MATERIAL AND METHODS}

\section{Preparation of specimens for immunofluorescence tests}

Bulbs of Allium cepa were grown at $26{ }^{\circ} \mathrm{C}$. When roots were $1.5 \mathrm{~cm}$ long, root tips were cut off, fixed in $45 \%$ acetic acid for $30 \mathrm{~min}$, washed in double distilled water and post-fixed in $4 \%$ paraformaldehyde (in $0.01 \mathrm{M}$ PBS, $\mathrm{pH}$ 7.4) for $1 \mathrm{~h}$. Then the root tips were washed in double distilled water, digested in a mixture of $0.5 \%$ cellulase and $0.5 \%$ pectinase for 4 to 6 h, hypotonized in double distilled water for $1 \mathrm{~h}$, and squashed in $45 \%$ acetic acid on slides. After coverslips were removed in liquid nitrogen, specimens were viewed with a phase contrast microscope and the selected ones stored in PBS.

In order to remove histones from the nuclei and chromosomes, some of the specimens were pretreated with $2 \mathrm{M} \mathrm{NaCl}\left(30 \mathrm{~min}, 4{ }^{\circ} \mathrm{C}\right.$ ) according to the protocols described by Berezney and Coffey[22] and Paulson et a1[23]. They were washed in double distilled water, digested in $40 \mu \mathrm{g} / \mathrm{ml}$ DNase I for $1 \mathrm{~h}$ at room temperature and then washed in PBS. Both pretreated and non-pretreated specimens were used for immunofluorescence tests. 


\section{Immunofluorescence tests}

Specimens were washed in PBS containing $0.5 \%$ Triton X-100, incubated with rabbit anti-actin antibodies (Sigma, A2668) or rabbit anti-tropomyosin antibodies (Sigma, T3651) (1:100 diluted with PBS) for $1 \mathrm{~h}$ at $37{ }^{\circ} \mathrm{C}$, and washed in PBS and in PBS containing 0.5\% Triton X-100. Specimens were then incubated with goat anti-rabbit IgG conjugated to FITC (Gibco BRL, 9817SA) for $1 \mathrm{~h}$ at $37{ }^{\circ} \mathrm{C}$ (1:200 diluted with PBS), washed in PBS and in double distilled water, covered with 90\% glycerin and observed with an Olympus BH2 microscope.

In order to obtain reliable results for immunofluorescence tests, another protocol was use in this study. The protocol was proposed by Moens and Earnshaw[24] and as follows: Specimens were rinsed in mix (PBS containing 0.05\% Triton X-100, 0.25\% gelatin, $0.005 \mathrm{M}$ EDTA) for $10 \mathrm{~min}$, blocked in holding buffer (PBS containing $0.05 \%$ Triton X-100, 0.3\% BSA) for $10 \mathrm{~min}$. They were then incubated with the rabbit anti-actin antibodies (1:40 diluted with holding buffer) for $1 \mathrm{~h}$ at $37{ }^{\circ} \mathrm{C}$ and overnight at $4{ }^{\circ} \mathrm{C}$. Specimens were washed in PBS and in mix, blocked in holding buffer, and incubated with goat anti-rabbit IgG antibodies conjugated to FITC for $1 \mathrm{~h}$ at $37^{\circ} \mathrm{C}$. They were finally washed in PBS and in double distilled water, covered with $90 \%$ glycerin and observed with a Nikon UFX microscope.

Controls included omission of the primary antibodies. These controls were run concurrently with each experiment and were invariably negative.

\section{Immunogold labeling and electron microscopy}

Root tips were fixed in a mixture of $2 \%$ glutaraldehyde and $4 \%$ paraformaldehyde (in PBS) for 2 $\mathrm{h}$, washed in PBS and in double distilled water, dehydrated in an ascending series of ethanol (25\%, $50 \%, 75 \%$ and $90 \%, 1 \mathrm{~h}$ for each) and kept in 90\% ethanol for $12 \mathrm{~h}$. They were then infiltrated in infiltration mixture 1 (Lowicryl K4M:90\% ethanol, 1:2, $12 \mathrm{~h}$ ) and mixture 2 (K4M:90\% ethanol, $2: 1,12 \mathrm{~h}$ ), followed by infiltration in pure $\mathrm{K} 4 \mathrm{M}$ (room temperature, $24 \mathrm{~h} ; 0{ }^{\circ} \mathrm{C}, 24 \mathrm{~h} ;-20{ }^{\circ} \mathrm{C}$, $24 \mathrm{~h})$. Specimens were placed in capsules and polymerized under UV light $\left(-35{ }^{\circ} \mathrm{C}, 24 \mathrm{~h}\right.$; room temperature, $24 \mathrm{~h}$ ).

Sections were cut on a Reichert-Jung ultromicrotome at a thickness of 70-80 nm and mounted on uncoated nickle grids (300 mesh). Grids were pretreated in a saturated $\mathrm{NaIO}_{4}$ solution for 45 min and in $0.1 \mathrm{~N} \mathrm{HC1}$ for $10 \mathrm{~min}$, washed in PBSTG (PBS, 0.2\% Tween-20, $15 \mathrm{mM}$ glycine) and blocked in BSA (1\% BSA in PBSTG, pH 7.4) for $15 \mathrm{~min}$. They were then incubated in anti-actin antibody (1:25 diluted with $0.1 \%$ BSA) for $1 \mathrm{~h}$ at $37{ }^{\circ} \mathrm{C}$ and overnight at $4{ }^{\circ} \mathrm{C}$. After washing in PBSTG ( $\mathrm{pH} 7.4$, then $\mathrm{pH}$ 8.0), they were incubated in a solution of protein A-10 nm colloidal gold (Sigma, 1:20 diluted with 0.1\% BSA) for $1 \mathrm{~h}$, washed in PBSTG (pH 8.0, then $\mathrm{pH} 7.4$ ) and double distilled water. The specimens were observed at $75 \mathrm{KV}$ with a Hitachi-600 electron microscope.

Control grids were exposed to $0.1 \%$ BSA instead of the antibodies. Nonspecific binding was not observed.

\section{RESULTS}

\section{Inmunofluorescence tests of actin}

Fluorescence microscopic observations upon non-pretreated specimens clearly showed that both intact nuclei and intact chromosomes of A. cepa were labeled with rabbit anti-actin antibodies (Figs 1 and 2). The interphase nuclei (arrow in Fig 1) were composed of fine fibrils which gave off bright fluorescence. At prophase, fluorescent fibrils that represented prophase chromosomes were thicker and brighter than that at interphase, and the fibrils twined with each other to form a network that retained the contour of the nucleus (arrowhead in Fig 1). At metaphase, structures with typical morphology of metaphase chromosomes showed intense labeling, 


\section{Actin in higher plant nuclei and chromosomes}

and longitudinal substructures representing sister chromatids in these metaphase chromosomes could be easily distinguished (Fig 2).

Observations on the specimens pretreated with $2 \mathrm{M} \mathrm{NaC} 1$ and DNase I further indicated that the DNA- and histone-depleted nuclei and chromosomes were also labeled intensely with the anti-actin antibodies (Figs 7-11). The nuclear antigen detected was found to be distributed throughout the DNA- and histone-depleted interphase nucleus which still showed the shape of intact nuclei (Fig 7). A network consisting of fluorescent fibrils was clearly seen in the prophase nucleus (Fig 8), the labeling signals showed that nuclear actin was mainly situated in the DNAand histone-depleted prophase chromosomes. The labeling pattern of the DNAand histone-depleted metaphase chromosomes (Fig 9) was similar to that of intact chromosomes (Fig 2). At anaphase, the DNA- and histone-depleted chromosomes were labeled and situated in one of the mitotic poles, they merged with each other to form a block and chromosome arms protruded from the periphery of the block (Fig 10). In the DNA- and histone-depleted telophase cell, two daughter nuclei sent forth bright fluorescence (Fig 11), showing much intenser labeling than that of the surrounding cytoplasm. It is worth indicating that the same labeling pattern was found in the specimens prepared with the two protocols for immunofluonescence.

\section{Immunogold labeling of actin}

Immunogold technique was used to confirm the presence of actin in nuclei of A. cepa. After reaction with the anti-actin antibodies and protein A-gold, sections of meristematic cells of A. cepa showed general labeling throughout the whole nucleus

$\triangleright$ Fig 1, 2. Micrographs showing intact nuclei and chromosomes of Allium cepa labeled with. rabbit anti-actin antibodies and FITC-conjugated goat anti-rabbit IgG antibodies. The interphase nuclei gave off prominent fluorescence, indicating the presence of actin in the interphase nuclei (arrow in Fig 1). The prophase nucleus contained fibrils which corresponded to the prophase chromosomes, and the fibrils showed labeling of actin and twined with each other to form a fluorescence network within the prophase nucleus (Fig 1). Metaphase chromosomes were intensely labeled (Fig 2). Note that the longitudinal substructures representing the sister chromatids in the metaphase chromosomes were distinguishable (Fig 2)

Fig 3- 5. Micrographs showing nuclei and chromosomes of Allium cepa labeled with rabbit antitropomyosin antibodies and FITC-conjugated goat anti-rabbit IgG antibodies. The intact interphase nuclei and prophase chromosomes sent forth bright fluorescence, demonstrating the existence of tropomyosin (Fig 3). The specimens were treated with DNase I and $2 \mathrm{M} \mathrm{NaCl}$ to remove DNA, histones and most of nonhistones from the nuclei and chromosomes. The DNA- and histone-depleted interphase nuclei and prophase chromosomes (Fig 4) as well as metaphase chromosomes (Fig 5) showed intense labeling of tropomyosin.

Fig 6. Electron micrograph showing a nucleus of Allium cepa which was labeled with antiactin antibodies and protein A-10 nm colloidal gold. Large amounts of the gold particles were distributed over the nucleolus and condensed chromatin, and a few gold particles were found in the interchromatin domains. 
Wan LH and M Xing
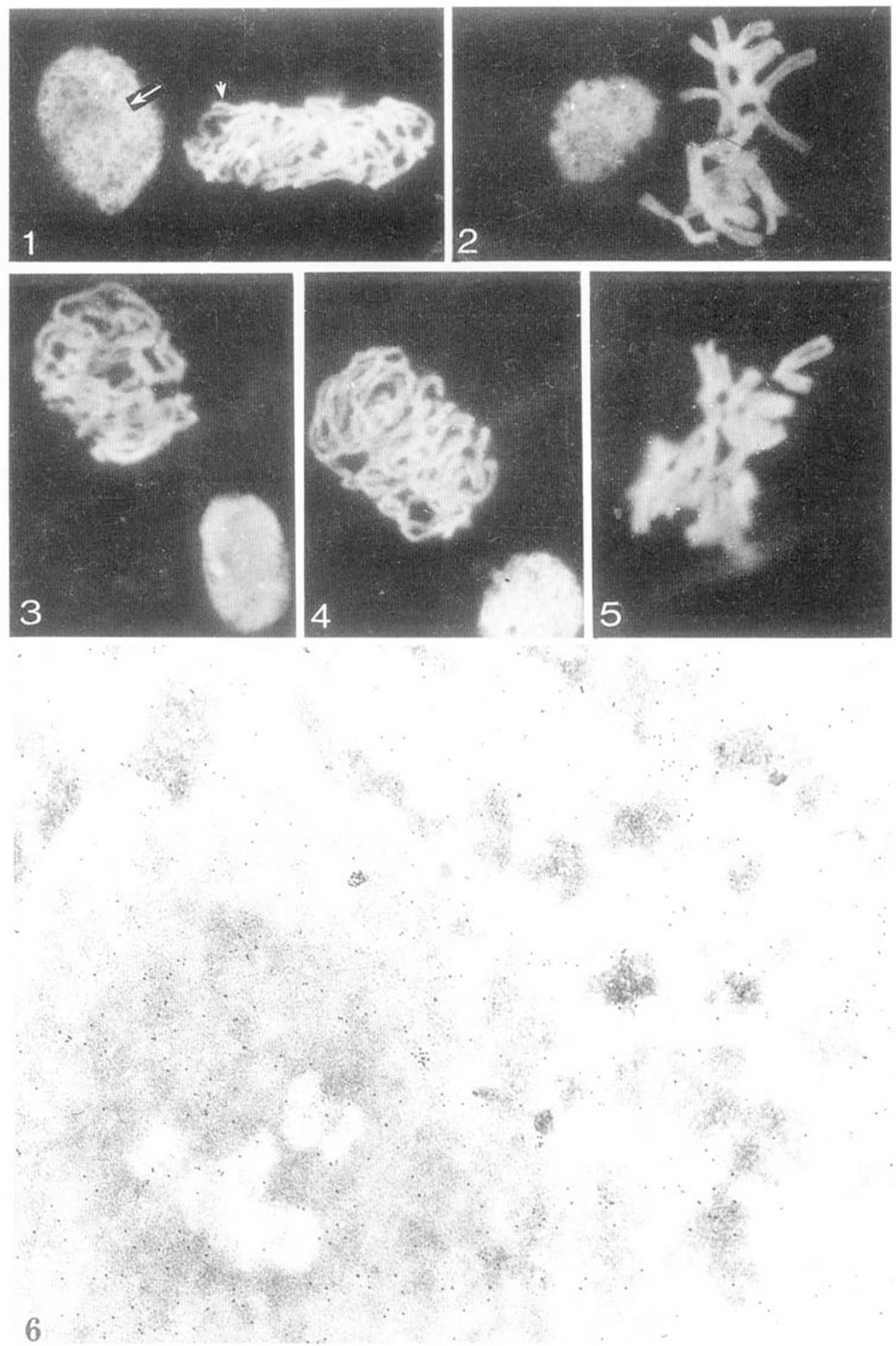
(Fig 6). The total number of gold particles and their density in different domains in the nuclei of both the labeled specimens and control ones were obtained (Tab 1) from analysis of the EM photographic plates by using IBAS image processing system, and the statistics of the several photographic plates may occasionally show a small difference from that observed in a single photograph. Analysis of distribution of gold particles revealed that a number of gold particles were concentrated upon condensed chromatin and nucleolar regions, only a few gold particles were located in interchromatin domains. The average density of gold particles in nucleoli was $34.17 / \mu \mathrm{m}^{2}$, and that in condensed chromatin was $23.37 / \mu \mathrm{m}^{2}$, while the density of gold particles in interchromatin domains was only $6.16 / \mu \mathrm{m}^{2}$ which was similar to that of the controls $\left(4.37 / \mu \mathrm{m}^{2}\right.$, Tab 1$)$.

\section{Immunofluorescence tests of tropomyosin}

The anti-tropomyosin antibodies directed against rabbit tropomyosin labeled both intact nuclei and chromosomes and DNA- and histone-depleted nuclei and chromosomes of A. cepa (Figs 3-5, 12). Prominent fluorescence was observed in intact interphase nuclei and prophase chromosomes (Fig 3), and also found in DNA- and histone-depleted interphase nuclei and prophase chromosomes (Fig 4). At metaphase and anaphase, DNA- and histone-depleted chromosomes showed similar typical labeling patterns (Figs 5 and 12), like that of actin in intact ones.

\section{DISCUSSION}

\section{Actin is a constituent of nuclei and chromosomes}

Actin was first isolated from vertebrate muscular cells and has been proved to be

Fig 7-11. Micrographs of DNA- and histone-depleted nuclei and chromosomes of Allium cepa. Specimens were treated with DNase I and $2 \mathrm{M} \mathrm{NaCl}$ to remove DNA, histones and most of the nonhistones from the nuclei and chromosomes, and then labeled with rabbit anti-actin antibodies and FITC-conjugated goat anti-rabbit IgG antibodies. The DNA- and histone-depleted interphase nuclei (Fig 7), prophase chromosome fibrils (Fig 8) and metaphase chromosomes (Fig 9) showed positive reaction to actin, and the labeling patterns were similar to those of the intact nuclei and chromosomes as shown in Figs 1, 2). Fig 10 showing the labeled DNA- and histone-depleted chromosomes at anaphase, the chromosomes were gathered together in one of the mitotic poles. Note that some chromosome arms protruded from the periphery of the merged block. Fig 11 showed the two daughter nuclei in one telophasic cell which has been depleted of DNA and histones. Note that the daughter nuclei gave much intenser labeling of actin than that of the surrounding cytoplasm.

Fig 12. Fig 12 showing the DNA- and histone-depleted anahpase chromosomes of A. cepa labeled with tropomyosin. Note the protrusion of chromosome arms from the merged block of chromosomes. 
Wan LH and M Xing
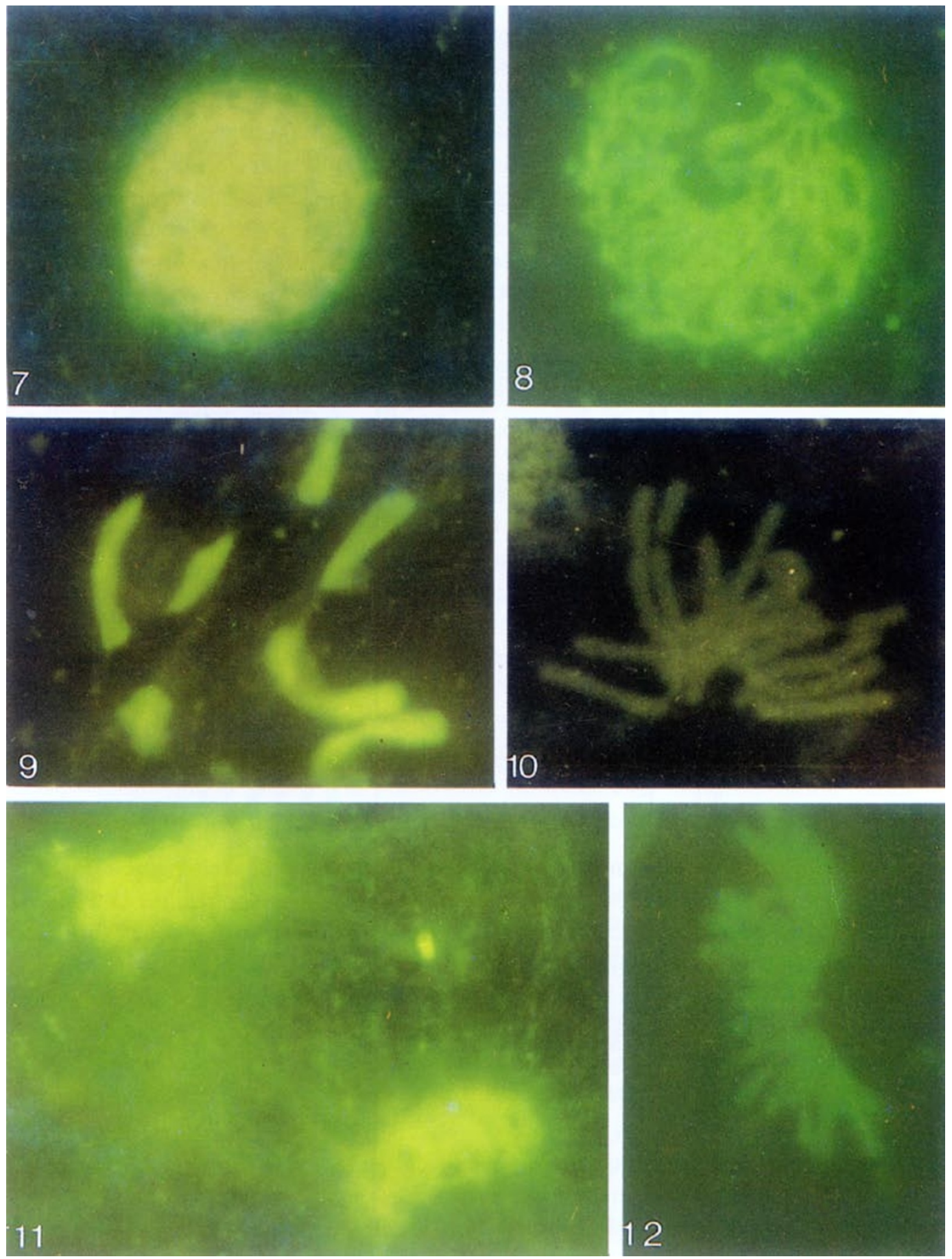
Actin in higher plant nuclei and chromosomes

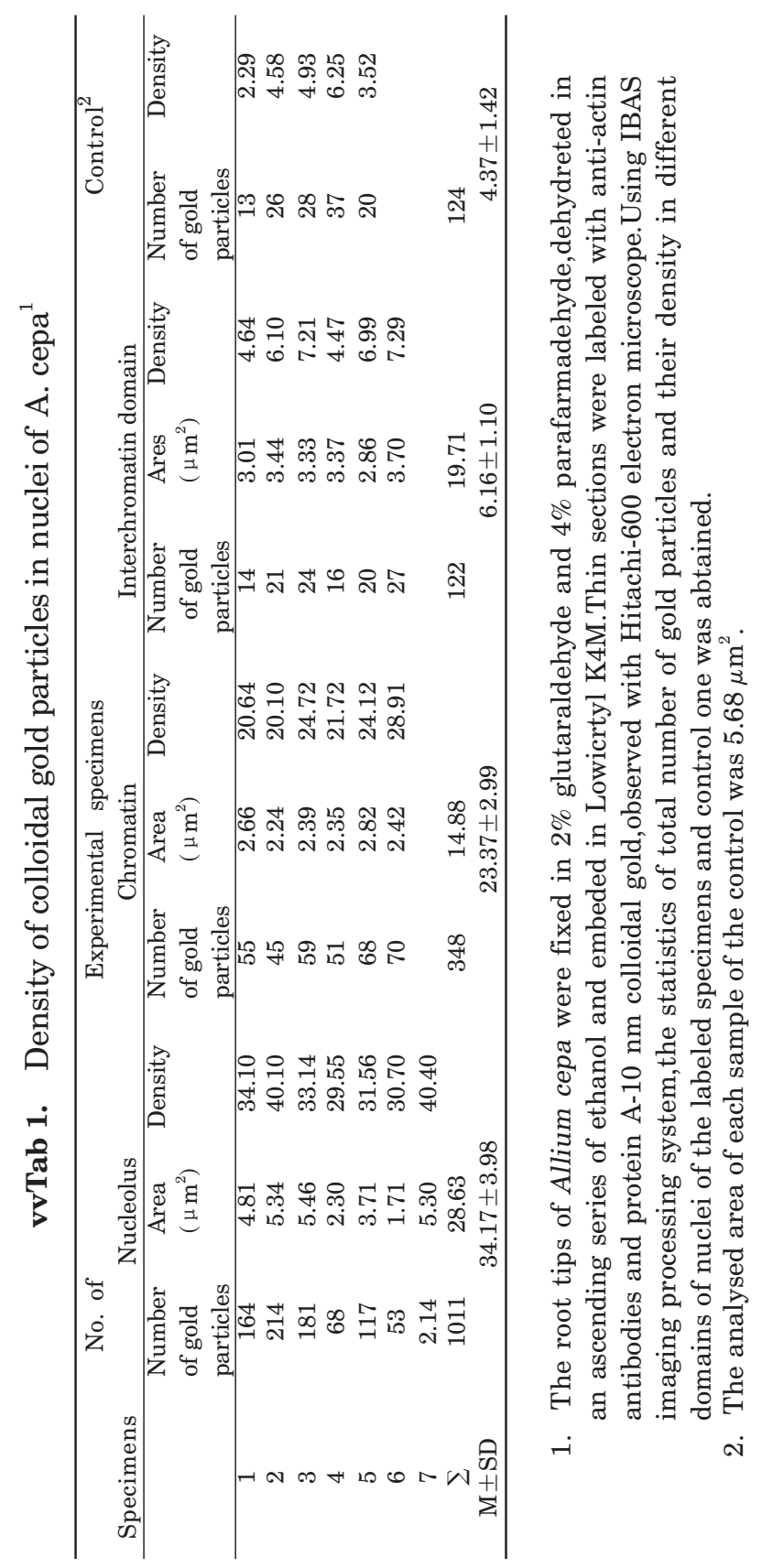


present as an important cytoskeletal protein in both muscular and non-muscular cells of eukaryotes[1]. Biochemical analysis has shown that actin occurs in isolated nuclei of slime mold[2, 5], of amphibian oocytes[7, 8, 11], of mammalian cells[3, 4, 6] and of cells of some other species (reviewed by References 17, 19). By using immunogold labeling and electron microscopy, Armbruster et al[16] localized actin in nuclei of Chinese hamster ovary cells. Recently, Milankov and Boni[17] demonstrated by immuno-confocal microscopy and ultrastructural immunogold labeling, that interphase nuclei of dorsal root ganglion neurons and of PC12 cells contain actin. Parfenov et al[19] further revealed at electron microscopic level that actin filaments are present in the nuclei of frog oocytes. Although many reports are found in the literature concerning actin in animal nuclei, the presence of the protein in nuclei and chromosomes of higher plants has not been well established.

In the present paper, meristematic cells of $A$. cepa were labeled with rabbit antiactin antibodies and FITC-conjugated goat anti-rabbit IgG antibodies and observed with fluorescence microscopy. Both the nuclei and chromosomes sent forth bright fluorescence, indicating that the nuclei and chromosomes contain actin. Sections of the meristematic cells were labeled with the anti-actin antibodies and protein A10nm colloidal gold and observed with electron microscopy. The gold particles were found over the nuclei, and a great deal of gold particles were concentrated on condensed chromatin and nucleoli, confirming that actin is a constituent of the nuclei of A. cepa. All these results are consistent with the recent observations upon actin component in nuclei and chromosomes of Vicia faba[25]. These results from higher plants, together with previous biochemical and immunocytochemical evidence from animals and lower plants, suggest that the existence of actin in nuclei and chromosomes is an universal phenomenon of eukaroytic cells.

\section{Actin is associated with DNA- and histone-depleted nuclei and chromosomes}

Previous reports have indicated that when mammalian cell are digested with DNase I to remove most of the DNA and extracted with high concentrations of salt (usually $2 \mathrm{M} \mathrm{NaCl}$ ) to remove histones, a fibrillar network of non-histone proteins remains in the region of the nucleus which has been termed as nuclear matrix. The DNA- and histone-depleted chromosome which retains the shape of the metaphase chromosomes is termed the chromosome scaffold[22-23, 26-33]. The first described component of proteins of the chromosome scaffold is DNA topoisomerase II[34-35], but the multiple protein components of the nuclear matrix and chromosome scaffold have not been fully characterized.

As here mentioned above, actin has been proved to be one non-histone protein in the nuclei and chromosomes of animal and lower plant cells[2, 3, 5, 16-19], and the data presented here further indicate that actin is also a constituent of nuclei and chromosomes of a higher plant Allium cepa. However, opinions upon whether actin occurs in the nuclear matrix and chromosome scaffold is still controversial. Capoco 
et al[20] reported that SDS-PAGE analysis shows a $43 \mathrm{kD}$ polypeptide in the nuclear matrix of HeLa cells and suggested that the polypeptide is possibly actin. Nakayasu and Ueda[14] indicated, on the basis of results of SDS-PAGE and Western blot, that four actin components are associated with the nucleus and nuclear matrix of mouse L5178Y cells. Pieck et al[21] revealed a $43 \mathrm{kD}$ polypeptide in SDS-PAGE analysis of chromosome scaffolds isolated from bovine liver cells but they considered it as a contamination of the cytoplasmic components. Recently, Zeng et a1[36] demonstrated that actin is a constituent of the nuclear matrix and chromosome scaffolds of a lower plant Physarum polycephalum.

In this paper, meristematic cells of $A$. cepa were treated with DNase I and $2 M$ $\mathrm{NaCl}$ to remove DNA and histones from the nuclei and chromosomes. After reaction with the anti-actin antibodies, fluorescence localizing the antigen was observed in the DNA- and histone-depleted nuclei and chromosomes. After comparing the fluorescence densities of non-pretreated and pretreated preparations and of preparations at different stages (interphase, prophase, metaphase, anaphase and telophase), two interesting points emerged. One is that non-pretreated (intact) nuclei and chromosomes and pretreated (DNA- and histone-depleted) nuclei and chromosomes show the similar fluorescence densities when they were labeled according to the same protocols. The another one point is that the antibody-directed antigen detected in the DNA- and histon-depleted preparations is mainly located in the chromosomes through the whole mitotic cycle i.e., from interphase to telophase. At interphase and prophase, the fluorescence is focused on the fibrils that represent the interphase and prophase chromosomes; at metaphase, anaphase and telophase, the brighter fluorescence is also displayed by chromosomes of these stages. All these observations lead to the conclusion that actin is not only present in intact nuclei and chromosomes but also present in the DNA- and histone-depleted nuclei and chromosomes. Although there is no indisputable biochemical data to indicate that actin is a constituent of the nuclear matrix and chromosome scaffold of $A$. cepa, our immunofluorescence results do provide new evidence supporting the point of view that actin is associated with the DNA- and histone-depleted nuclei and chromosome of the higher plant.

\section{Tropomyosin is present in nuclei and chromosomes}

Tropomyosin is one of actin-binding proteins, which usually coexists with actin in a wide range of cytoplasmic structures and stabilizes actin filaments by binding along the length of the filaments[1]. Douvas et al.[3] reported that tropomyosin is one of non-histone proteins of rat liver chromatin. In the present paper, immunofluorescence observations indicate that tropomyosin occurs in both intact and DNA- and histone-depleted nuclei and chromosomes. In addition, the distribution of tropomyosin during the whole mitotic cycle is similar to that of nuclear actin. Based on these results, it is tempting to suggest that tropomyosin also functions as an actin-binding protein in the nuclei and chromosomes. 


\section{ACKNOWLEDGEMENTS}

This work was supported by the grant of the Trans-Century Training Program Foundation for the Talents by the State Education Commission of China.

\section{REFERENCES}

[1] Alberts B, Bray D, Lewis J, Raft M, Roberts K, Watson JD. Molecular Biology of the Cell, 3nd Edition, Garland Publishing Inc., New York. 1994; 821-34.

[2] Jockusch BM, Becker M, Hindennach L, Jockusch H. Slime mold actin: homology to vertebrate actin and presence in the nucleus. Exp Cell Res 1974; 89:241-6.

[3] Douvas AS, Harrington CA, Bonner J. Major nonhistone proteins of rat liver chromatin: preliminary identification of myosin, actin, tubulin and tropomyosin. Proc Nat Acad Sci USA 1975; 72:3902-6.

[4] Lestourgeon WM, Foreer A, Yang YZ, Bertram JS, Rusch HP. Contractile proteins: major components of nuclear and chromosome nonhistone proteins. Biochem and Biophy Acta 1975; 379:529-52.

[5] Lestourgeon WM. The occurrence of contractile proteins in nuclei and their possible functions. In: Busch ed. The Cell Nucleus. Vol 6, New York: Academic Press, 1978; 305-326.

[6] Peterson JL, McConkey EH. Non-histone chromosomal proteins from HeLa cells. Journal of Biological Chemistry 1976; 251:548-54.

[7] Clark TG, Merriam RW. Diffusible and bound actin in nuclei of Xenopus laevis oocytes. Cell 1977; 12:883-91.

[8] Clark TG, Rosenbaum JL. An actin filament matrix in hand-isolated nuclei of X. laevis oocytes. Cell 1979; 18:1101-8.

[9] Pederson T. Isolation and characterization of chromatin from the cellular slime mold Dictyostelium discoideum. Biochemistry 1977; 16:2771-7.

[10] Farr RM, Luckow V, Sundharadas G. Major nonhistone proteins of bovine lymphocyte chromatin: identification of tubulin and actin. Exp Cell Res 1979; 121:428-30.

[11] Gounon P, Karsenti E. Involvement of contractile proteins in the changes of oocytes of the newt Pleurodeles waltlii. J Cell Bio 1981; 88:410-21.

[12] Bremer JW, Busch H, Yeoman LC. Evidence for a species of nuclear actin distinct from cytoplasmic and muscle actin. Biochemistry 1981; 20:2013-7.

[13] Rubin RW, Goldstein L, Ko C. Differences between nucleus and cytoplasm in the degree of actin polymerization. J Cell Biol 1978; 77:698-701.

[14] Nakayasu H, Ueda K. Preferential association of acidic actin with nuclei and nuclear matrix from mouse leukemia L5178Y cells. Exp Cell Res 1986; 163:327-36.

[15] Sahlas JD, Milankov K, Park PC, De Boni U. Distribution of SnRNA, splicing factor SC-35 and actin in interphase nuclei: immunocytochemical evidence for differential distribution during changes in functional states. J Cell Sci 1993; 105:347-57.

[16] Armbruster BL, Wunderli H, Turner BM, et. al. Immunocytochemical localization of cytoskeletal proteins and histone $2 \mathrm{~B}$ in isolated membrane-depleted nuclei, metaphase chromatin and whole Chinese Hamster Ovary cells. J Histochem Cytochem 1983; 31:1385-93.

[17] Milankov K, De Boni U. Cytochemical localization of actin and myosin aggregates in interphase nuclei in situ. Exp Cell Res 1993; 209:189-99.

[18] Amankwahm KS, De Boni U. Ultrastructural localization of filamentous actin within neuronal interphase nuclei in situ. Exp Cell Res 1994; 210:315-25.

[19] Parfenov VN, Dacis DS, Pochukalina GN, Sample CE, Bugaeva EA, Murti KG. Nuclear actin filaments and their topological changes in frog oocytes. Exp Cell Res 1995; 217:385-94. 


\section{Actin in higher plant nuclei and chromosomes}

[20] Capco DG, Wan KM, Penman S. The nuclear matrix : three-dimensional architecture and protein composition. Cell 1982; 29:847-58.

[21] Pieck ACM, van de Veelder HMW, Rijken AAM, Neis JM, Wanka F. Protein composition of the chromosomal scaffold and interphase nuclear matrix. Chromosoma 1985; 91:137-44.

[22] Berezney R, Coffey DS. Identification of a nuclear protein matrix. Biochem Biophy Res Commun 1974; 60:1410-7.

[23] Paulson JR, Laemmli UK. The structure of histone-depleted metaphase chromosomes. Cell 1977; 12:817-28.

[24] Moens PB Earnshaw WC. Anti-topoisomerase II recognizes meitotic chromosome cores. Chromosoma 1989; 98: 317-322.

[25] Wan LH, Xing M. Actin is immunolocalized in the nuclei and chromosomes of Vicia faba. Acta Botanica Sinica. 1997; 39(8):685-90.

[26] Adolph KW, Cheng SM, Laemmli UK. Isolation of a protein scaffold from mitotic HeLa cell chromosomes. Proc Nat Acad Sci USA 1977a; 74:4937-41.

[27] Adolph KW, Cheng SM, Laemmli UK. Role of nonhistone proteins in metaphase chromosome structure. Cell 1977b; 12:805-16.

[28] Hao S, Xing M, Jiao MD. Chromatin-free compartments and their contents in anaphase chromosomes of higher plants. Cell Biol Intern Rep 1988; 12:628-35.

[29] Laemmli UK, Cheng SM, Adolph KW, Pauslon JR, Brown JA, Braumbach WR. Metaphase chromosome structure: the role of nonhistone proteins. Cold Spring Harbor Symp Quant Biol 1978; 42:351-60.

[30] Boy de la Tour E, Laemmli UK. The metaphase scaffold is helically folded: sister chromatids have predominantly opposite helical handedness. Cell 1988; 55:937-43.

[31] Newport JW, Forbes DJ. The nucleus: structure, function, and dynamics. Annual Review of Biochemistry 1987; 56:535-66.

[32] Xing M, Hao S. RNP structure in metaphase chromosomes of Vicia faba. Science in China, Series B 1989; 32:706-10.

[33] Zhao J, Hao S, Xing M. The fine structure of the mitotic chromosome core (scaffold) of Trilophidia annulata. Chromosoma 1991; 100:323-9.

[34] Earnshaw WC, Halligan B, Cooke CA, Heck MMS, Lin LF. Topoisomerase II is a structural component of mitotic chromosome scaffolds. J Cell Biol 1985 a; 100:1076-1015.

[35] Earnshaw WC, Heck MMS. Localization of topoisomerase II in mitotic chromosomes. J Cell Biol 1985b; 100:1716-25.

[36] Zeng XL, Jiao MD, Wang XG, Hao S. Actin is a constituent of the nuclear matrix and chromosome scaffold in Physarum polycephalum. Acta Botanica Sinica. 1997; 39:691-6.

Received Dec-22-1997. Revised Feb-23-1998. Accepted Feb-24-1998. 